\title{
The Quiet Continent: Religion and Politics in Europe
}

\section{COLIN CROUCH}

COMPARED with the other world regions discussed in this book, contemporary Europe seems religiously to be a very placid place. While large majorities of European populations still profess to basic beliefs in God, participation in public acts of worship has dropped to low levels in most countries. ${ }^{1}$ In those where it remains relatively high (mainly Ireland, Italy and Poland), it is nevertheless declining rapidly. Behavioural adherence to church teachings also seems to have experienced a severe collapse; the fact that two of the most Catholic countries in Europe (Italy and Spain) now have lower birth rates than highly secular, post-Lutheran Scandinavia provides an eloquent indicator of this.

With reference to the theme of principal interest to this volume-the relationship between religion and politics-there is a similar story of passivity and decline. From the 1970s onwards, the Catholic Church suffered reversals on public policy issues close to its concerns-divorce, contraception and abortion-in Germany, Italy, Spain and more recently Ireland, sometimes in popular referenda among nominally Catholic populations. Meanwhile mainstream Protestant churches long ago gave up trying to exercise much political muscle. The main political achievements of 20th century European Christianity, the Christian democratic parties, were during the 1990s beset with financial and other moral scandals in Italy, Germany and Belgium. While socialist and other parties often shared these problems, they have struck fundamental blows at Christian democracy's claim to moral status.

European Christianity shows few signs of the fundamentalist enthusiasm affecting Christianity in both the USA and many parts of Latin America, a fact which currently leads American Christianity more closely to resemble Islam or Hinduism than its European sister. ${ }^{2}$ It is also notable that European Christian quietude extends to both eastern and western parts of the continent. A widely anticipated revival of religion in Eastern Europe following the fall of communism has failed to materialise. While this might have been expected in Orthodox lands, where national churches had come to terms with the Soviet state in the same way that they had for centuries with previous regimes, it has been more surprising in former Catholic countries. This is particularly so in Poland, virtually the most Catholic country in Europe, where the Church had played a major role in organising opposition to the communist regime through its support of the Solidarnosc movement, and through the work of Karol Woytila, the Polish Pope John Paul II. This inability of the east European Christian churches to take advantage of the collapse of communism 
contrasts strongly with the role of Islam in the southern parts of the former Soviet empire.

Viewed globally it is legitimate to talk of the 'exceptionalism' of current European secularism. However, if one takes a closer look matters appear more complex. First, if one limits attention to the industrialised world, and takes account of the similar passivity of religion in Australasia and in Japan (both Shinto and Buddhism), it becomes the USA which is the exception. Outside that country it is superficially still possible to argue that modernisation brings with it secularisation, consistent with 19th century rationalist expectations of the incompatibility between a religious standpoint and that of modern science. The USA might then be explicable in terms of its peculiarity as a society of immigrants. The fact that on virtually any indicator the European country which has become most secular and contrasts most strongly with the USA is England, ${ }^{3}$ early to modernise and the case which on so many other issues seems to lie partway between the old continent and America, encourages us in this view.

However, this perspective becomes in turn more questionable if we move still closer. First, most evidence of European secularisation has been very recent. The early stages of industrialisation were associated with waves of religious enthusiasm and revival, notably indeed in 19th century Britain. ${ }^{4}$ Even in France, which embarked on a long and dramatic opposition to religion in 1789, it was not until the final third of the 20th century that such things as declining church attendance became strikingly apparent. In general, and with the exception of England, the major decline in European church attendance was a phenomenon of the second half of the 20th century. ${ }^{5}$ By that time decline in religious participation could be ranked alongside declines in other publicly oriented activities, such as attendance at sporting events or active participation in political parties. It is not at all clear that the main process at work has been some scientific rejection of religious belief. Consistent with this observation is the fact that decline in actual beliefs seems far less marked than that in practice.

Also relevant here is the important insight of David Martin that it was the clash between church and state rather than that between church and science that was fundamental to the weakening of European Christianity in the context of modernisation. ${ }^{6}$ In Catholic lands the rejection by the Church of the autonomy of the secular state in the late 19th century, and particularly in the context of the struggle over the control of mass education, led to the alienation of large parts of the population. The Lutheran state churches in Nordic countries, and in a slightly different way the Church of England, took a very diverse path. They had already accepted the comfortable and official role assigned to them by the state, but at the expense of retaining any popular mobilising power, which latter then became embodied in non-conformist and dissident Protestant sects and denominations. This thesis cannot account for the subsequent and rapid demise of non-conformism, but it does help explain the difference between European and US American experience. Because no 
church was permitted to become an official church in the young USA, religion was left uncontaminated by either church-state conflict or official quietude. It could work without restraint at creating and sustaining enthusiasm, drawing on the important reservoir of immigrant memory in so doing.

Religions of ethnic minorities typically sustain considerably higher levels of adherence than those of the national majority. This is as true of Christian minorities (such as members of both the various Caribbean churches and of the mainly Irish Catholic church in England) as it is of Moslems, Hindus and others. Jews in the Diaspora are more likely to attend synagogue than those in Israel; British Anglicans in expatriate communities are more likely to attend church than those in England. The rhythm of minority religions is very different from that of majority ones. It is a poignant indicator of the security eventually felt by a minority group within its host society when its religion starts to decline. This role of religion as a signifier for ethnic minorities has been particularly important in the life of American citizens, large numbers of whom can see themselves as some kind of ethnic minority.

In this way we can gradually separate the debate over secularisation from simple stories of a modernisation trajectory, and both understand contrasts between Europe and America and also start to approach the internal dynamics of European religion and its weakening.

Grace Davie has described the state of contemporary European religion in terms of 'believing without belonging'; $;$ it is not belief in God and Christ which has been challenged, but participation in the formal organisations that represent religious belief. This would seem to be a reasonable conclusion based on the English case, but there are problems in generalising it. In a review of religious belief and practice in Germany, Kecskes and Wolf were not able to find evidence of a difference between disbelief (Glauben) and experience (Erfahrung); rather, people exhibited to different degrees a 'general religiosity' (allgemeine Religiosität). ${ }^{8}$ Only level of religious knowledge seemed to identify a distinctive group. They found similar evidence from studies in the USA. Gerda Hamberg has perceived a process in Sweden which, in direct contrast with Davie, she calls 'belonging without believing'. ${ }^{9}$ Although very few Scandinavians attend church or profess religious beliefs, the great majority of teenagers continue to take the fairly strong and active step of being confirmed into the Lutheran faith; and hardly anybody bothers to seek exemption from the voluntary church taxes. More generally in western Europe rates of christenings, confirmations and funerals remains high; religious weddings have declined in the long run, but in most countries have stabilised and even risen slightly in very recent years. The only exceptions to these patterns are England and, following a very recent and rapid decline, the Netherlands. In Germany, where, as in the Nordic countries there are voluntary church taxes, the vast majority continues to pay them. 
Furthermore, European churches have not completely lost their capacity to act as rallying points for political and moral claims, in very diverse ways. Government challenges to the place of church schools in France and Spain during the 1980s led to major protest movements. The collapse of the Christian democratic party in Italy did not lead to the disappearance of Christian democracy, but to its split into three parties, each following a coherent part of the previously very heterogeneous legacy of the movement and thus aligning with left, right and centre. If anything, Catholic social thought has thereby been able to spread its influence more diffusely through Italian political life. Even in the UK during the 1990s public expressions of grief at the untimely deaths of John Smith, then Leader of the Labour Party, and Diana, Princess of Wales, sought for essentially religious forms. In Scandinavia, especially Norway, Protestant Christian movements have shown a surprising new capacity to articulate public discontent over certain directions taken by modernisation, particularly abortion-though this, as well as European Catholic anti-abortion campaigns, take a very different form from the sometimes murderous activities of the anti-abortion movement in the USA.

We can agree with Grace Davie and her colleague Danièle Hervieu-Léger when they argue that contemporary Europeans seem merely to want to know that religion is there, that the churches continue to exist, even if they do not want to do very much to guarantee their existence or spend much time inside them..$^{10}$ Serious proposals for the abolition of religions would be opposed by very many who were neither members or even believers. There is, as Davie expresses it, a religious 'memory', which 'mutates'. ${ }^{11}$ At one extreme this can be little more than an affection for historic buildings and practices providing a link with earlier times; at the other it indicates a concern to have continued access to sources of values not otherwise available within modern society nor created by its massive diversity of institutions and intellectual productions. In particular, people need to come to terms with difficult issues raised by contemporary scientific advance, especially in the medical field. Decisions about the termination of lives of those being artificially sustained by medical apparatus, the ethics of transplant surgery, the use of human genetic material and similar developments are raising moral dilemmas which no secular system of thought-certainly not that of science itself-can really answer. Churches are among the few institutions which have developed anything like expertise on these questions, and their experts are turned to as relevant, even by those who do not necessarily support the conclusions they reach.

The reaching for a religious memory, which is involved in both a minimal 'heritage' approach to religion and a more profound searching for help with timeless and unanswerable ontological questions, relates also to the search for meaning and identity which are always fundamental to religious matters. Pursuing this path then helps us both to explore further the continuing value Europeans place on their religions, and the reasons for the prevailing weakness of those religions. 


\section{Identity and Individualism}

One of the clearest abiding strengths of religion for modern and even for selfproclaimed post-modern populations is its capacity to confer identity, to help answer the question 'who am I?' In this basic respect, early 21st century men and women differ little from their predecessors throughout human history. In order to make use of the superior intelligence and sensitivities that our species enjoys in relation to those of other animals, we require some sense of meaning. The routine of dust to dust and ashes to ashes, or the idea that we are simply the means by which DNA reproduces itself, seem otherwise to mock and render worthless all that intelligence and sensitivity, our capacity to love and therefore to grieve and to mourn loss. Religions, which relate our lives to a wider cosmos and inform us of a meaning and purpose, have long filled this need. Secular religions, which teach us to relate our lives to the unfolding of a particular history-of an ideology, a nation, a movement, perhaps today of a great corporation-can often achieve the same ends, but religion has repeatedly shown a capacity to outlast these others. It is only for a reflective minority that the great ontological questions appear as a frequent and pressing concern, but from time to time very many people pay some attention to them, and they like to know that there is something with which they can identify which resolves these matters for them, and that there are some specialists out there who devote their care and intellects to looking after it all. At certain moments-typically deaths and disasters-everyone temporarily draws closer to these specialists. For the rest of the time it is enough to know that they are there; and it would be very unsettling if they disappeared.

But identity is not primarily abstract and intellectual. It is mediated through membership of a wider collectivity of those who share it. For day-to-day purposes, the meaning of being, say, a Roman Catholic is not to entertain certain active beliefs in the precise character of the Holy Trinity or transubstantiation. It is to live among other Catholics and to know oneself to be one of that group rather than of another. With the exception of extreme forms of anchorites and hermits, religious life, whether serious and professional or that of marginal acknowledgements, comprises shared membership of a human community of similar others, a membership which in turn relates the individual to some more external source of meaning. Although original Protestantism insisted on the ability and duty of the individual to communicate directly with God, Protestants rapidly formed communities, churches and other groupings. In religious terms their individualism has come to mean largely a capacity for organisational fission and fragmentation of group, not individualistic isolation.

This is what remains of religious faith after all kinds of specific beliefs have been discarded or refuted: a sense of linkage to a profound source of meaning, mediated through membership of a recognised human community of fellow adherents. The precise status of beliefs-about the place of the earth within 
the universe, the creation of species, or the problematic character of the soul in the context of modern medical capacities artificially to sustain life-do not ultimately matter if identities of this kind are at stake. This explains why Christianity has bounced back after any number of refutations of its specific claims.

If the provision of identity has been a stable aspect of the role of religion over a long historical period, the particular form of that role has changed enormously. It can include making sense of the universe and one's place in it. It can imply an obligation to assist, and a right to claim assistance from, others with the same identity; and a similar obligation to shun or even hate those with a different one. Or, as sometimes today, religious identity can be almost a kind of fashion item: a set of distinguishing characteristics chosen within a market of alternatives in order to be associated with a trend, possibly to be discarded when the fashion changes. In at least this last form identity is very compatible with the contemporary stress on individuality. We assert our personal identity through a series of affirmations of particular characteristics, whether these are a matter or profound beliefs or modes of eating and dress. The particular package we construct forms our individuality, but nearly all the specific components are drawn from identities-even or perhaps especially fashion-oriented ones-shared with others and which normally align the self with those others and indicate a willingness to conform with their ways in order to demonstrate acquisition of the identity. Only very rarely is individualism expressed as complete isolation from a group, and this usually marks out the individual concerned as somewhat strange. Usually individuality is bounded by strong contextual referents. The Greek monks who practise the individualised rituals made possible by the Greek Orthodox Church do so within the recognisable collective frame of Greek Orthodoxy. The extraordinary range of idiosyncrasies practised by Californians are recognisably Californian.

However, by the late 20th century people in the advanced countries seemed more concerned than in certain past periods to construct individual personal packages of such identities. This is not just post-modern theorising about the behaviour of a few exotic cultural elites, but something which sociological research shows us to have been taking place in at least rudimentary form on a very widespread basis. For example, research on the family suggests that young people now have very high expectations of individual fulfilment from relationships and wish to be able to revise decisions and commitments that do not succeed; a low value is placed on commitment to others as opposed to the achievement of the aims of the needs of the individual self-a point which seems to explain the paradox that divorce rates are usually higher among those who postpone marriage until a trial period of cohabitation than among those who make an early commitment to marriage. ${ }^{12}$ In such a context, people become very wary about how much heteronomy they are accepting if they adopt an identity in its entirety, and they therefore seek to negotiate their own personal formula within it. 
There are difficulties when such a concept of individuality confronts the concept of organisational authority which forms a fundamental part of the community of most forms of European religion. At this point a closer look at contemporary American Christianity provides valuable clues. The large, rather hierarchical forms which are dominant in European Christianity and which are there experiencing decline are also having difficulties in their capacity to attract and retain adherents in the Americas: in the USA Roman Catholicism, Lutheranism, Episcopalianism; in Latin America Catholicism. The ones that thrive in both north and south America are the more loosely structured, constantly fragmenting and re-forming forms of Protestantism.

The apparent capacity for mobilisation embodied in a faith like Catholicism in Italy, where 75 per cent of the population are to be found in church monthly, or Lutheranism in Sweden, securing confirmation in the faith by 80 per cent, is illusory. The compromise between European churches and their populations is that tokens of identity will be retained and even valued, but this comes at the price of the church not being able to insist on any behavioural conformities in return.

The kind of conformity required by the classic organised churches threatens individualism as it came to be understood in the late 20th century. Europeans seem to solve this problem by retaining certain basic links to their faith (such as confession of very rudimentary beliefs, confirmation, payment of a church tax or very occasional participation in Communion), but they are not prepared to get sufficiently close to their church to permit its organisational hierarchies to determine their life choices. In the USA, where there has never been an established church, it is easier to adopt the alternative solution, not so readily available to Europeans with their strongly rooted concepts of what constitutes a church, of choosing from a variety of very loosely structured forms of church and founding new ones at frequent intervals. A further alternative, practised by small but prominent groups of Americans and to a lesser extent Europeans, is to shift to one or other of the non-Christian, nontraditional forms of new age religion. This does not mean that no forms of American new Protestantism or new age religion impose strict requirements on their adherents. Some of them certainly do. However, the particular package of rules has been selected by the individual within a market of alternatives; it is not simply presented as already existing as dominant within the community and prior to the individual's choice as is the case with the standard forms of organised Christianity.

Campiche, using the terminology of Pierre Bourdieu, makes a similar point when he remarks that young Swiss people still want un habitus religieux; but they will not accept une tradition confessionnelle. ${ }^{13}$ Willaime describes how young French people have similarly indicated their desire for an individually defined religion in replies to opinion polls. ${ }^{14}$ At its weakest this amounts to religion as an element of life-style, alongside one's taste in music or perhaps only as a fashion statement; Willaime talks of religion à la carte. Voyé makes the point with reference to contemporary Belgium-though he could have 
referred to almost anywhere in contemporary Europe-that while people are willing to adhere to the great rites of the Church, they are no longer willing to obey it..$^{15}$ Similarly in Italy, home of the Vatican, the Catholic church survives (and in many respects thrives) by accepting considerable diversity in beliefs and religious practice. ${ }^{16}$

Churches have been becoming more tolerant of their members discovering their own form of worship and faith within the framework of previously dogmatic forms. This is seen perhaps most strongly in both Catholic and Protestant churches in the Netherlands and Switzerland. In these religiously plural societies, once Catholic and Protestant hierarchies had begun to take an ecumenical approach towards each other, it was difficult to sustain a rigid insistence on doctrine within any one church; less than a third of Swiss Christians believe that there is any important doctrinal difference between the two principal forms of western Christianity. ${ }^{17}$ This is a point to which we shall return.

In addition to these recent changes, which the Catholic Church joined at the time of the Second Vatican Council under Pope John XXIII, some European churches have long embodied this kind of internal diversity: Danish Lutheranism; the diversified localism of Spanish Catholicism; Greek Orthodoxy. Also, in general the major European churches are today less challenged by either internal fragmentation or organised secularism than in the 19th century. Indeed, organised anti-religion has suffered far greater reversals than organised religion, with the collapse of humanist, Marxist and other organisations. This has, however not been enough to protect them from the consequences of individualisation. To explain this, we must search for some further problems of European Christianity, and we can find these by moving closer to the core theme of this volume: the relationship of religion to politics.

\section{The Problematic Politics of European Christianity}

In the immediate post-war period Christian democratic parties proved to be the most potent single political force in western Europe, dominating politics in several countries-principally Germany, Italy, Austria, the Netherlands and Belgium-and informing the foundation of the European Economic Community. This dominance had not been anticipated. The Catholic Church itself had expected a continuation of the earlier growth of an aggressively secular liberalism and even more aggressive socialism or communism which had successively dominated political change between the French Revolution and the rise of fascism. Catholic social thinkers were preparing the latest twist to the Thomist doctrine of subsidiarity to protect the rights of Christian localities against what were expected to be inevitably secularist, centralising national governments.

Before the Second World War Christian democrats had been a minority force even within Christian politics, many other elements of which were not at all at ease with the trade unionism, support for welfare spending and 
redistribution that democratisation implied. In the period between the two world wars most forms of continental European conservatism, Christian or lay, which had not adopted a Christian democratic path had become associated with fascism or nazism, and by 1945 were politically discredited. ${ }^{18}$ Not only was Christian democracy the only force capable of displaying proven democratic credentials while contesting both liberalism and socialism, but it became the banner under which all anti-liberals and anti-socialists had to rally, whatever their previous politics. In the process Christian democracy both grew in size and lost much of the radical edge of its policies. ${ }^{19}$

There were other aspects of the legacy of the first half of the 20th century, and of the Cold War which succeeded it for most of the second half, which had further consequences for the character of post-war Christian politics. In the wake of fascism and nazism, animosities and hatreds based on ethnic and other forms of cultural difference, once quite fundamental to many aspects of Christian identities, became completely taboo for all responsible, large-scale religious organisations. Particularly in Germany, this aversion to a politics of hostility and accentuation of differences was compounded by a sense that divisions among Christians, and also between them and other anti-totalitarian forces, had made possible the dominance of nazism in the first place. A repetition must not be risked. An ecumenical spirit among Christians and a hand of friendship to democratic and tolerant non-Christians became de rigeur.

A second fundamental condition of the post-war years was the need to avoid a communist future. Liberal and social democratic opponents could no longer be regarded by Christian politicians as anathema, since links with them were needed in a common anti-communist front. They might be organised in different parties, but compromises must be made with their policies, and they must be accepted as potential coalition partners. This was particularly important in France and Italy, where communist parties dominated working-class politics.

These various factors combined to impart a new and initially clear profile to post-war European Christian politics: it had to be ecumenical, accommodating, peace-loving-except where communism and any fascist recidivism were involved. It could not allow itself and the identities it conferred to be used to define boundaries of enmity and hatred. In Germany, Catholics and Protestants joined political forces within one party; in the Netherlands and Switzerland they intensified their already existing accommodations with each other. A rapprochement had to be made with, and forgiveness sought from, the surviving remnant of European Jewry. And as new non-Christian immigrants began to arrive from Islamic and other parts of the world during the 1960s, the established churches were careful to avoid any implication in racist movements, but preached toleration and the need to provide a welcome.

Important exceptions can be found to all this; specific groups, including priests, involved themselves in fascist, racist or anti-immigrant movements; and such movements could use an historical Christian rhetoric to defend their 
stances. Accepted anti-communism could be used as a pretext for fundamentalist opposition to a wider range of politics. As late as the mid-1950s Dutch Catholic bishops threatened excommunication to anyone voting for the Labour Party, moderately social democratic though that party was. But, with the exception of that last, most actions of this kind were minoritarian, secret, and likely to be greeted with repulsion by mainstream church leaders. ${ }^{20}$

Distinctive though this profile of tolerance was, it imparted an ultimately debilitating character to post-war European Christianity. An identity which is reluctant to stress its separateness from others and refuses to stir up latent antipathy towards outsiders is fighting with one hand tied behind its back. Harmless, and therefore rarely hated itself, it could remain as a quiet source of identity; people could be glad that it was still there. But its capacity for militant mobilisation was lost. A Dane might feel that her residual attachment to the national church was an important if placid expression of her Danishness; but she could not then use it to express her resentment at the arrival of Arabs and Turks in the streets of Copenhagen, because church leaders would be stressing tolerance.

On the other hand, in asserting their distinctiveness within a host society, the ethnic and religious minorities that are increasingly to be found within European societies have not needed to express hostility and aggression towards the majority, though in some cases they might do so. A perceived need to retain an important indicator of distinctive identity provides an adequate motive, which may extend in its intensity from a fear of extinction of a heritage to a fashion statement. For a majority culture or ethnicity to respond in a similar way appears, however, aggressive.

Two contrasting examples express all these points particularly well. Both the Netherlands and Northern Ireland contain large Catholic and Protestant (mainly Calvinist) populations; both societies have organised virtually their entire public life around this division for a considerable time. To know the religion of a Dutchman or Ulsterman was also to know which newspapers he would read, to which voluntary organisations he would belong, in which streets he was likely to live, which sports teams he was likely to support, and of course for which parties he would vote. In the Netherlands this framework of separation, once a source of considerable inter-community antagonism, was pacified by being formally recognised and incorporated into a system of cross-faith co-operation. This was in turn gradually affected by the post-war European context of rapprochement. Little or nothing was done to stress separateness and difference; opportunities for co-operation were always seized. While the organisational forms embodying the different communities have survived, they have lost meaning and purpose in everyday life. From being one of the countries with the highest levels of religious service attendance in Europe, the Netherlands changed rapidly from the late 1960s onwards to rival England in its absence of religious observance. 
Northern Ireland was entirely exempted from the general post-war trends in religion and politics described above by the fact that the dispute over the political status of the territory kept alive the Reformation conflict and, more specifically, the armed conflict on Irish soil in the 1680s between Catholic and Protestant claimants to the English throne as more salient events than the confrontations with fascism and communism on which minds were concentrated elsewhere in Europe. Catholics and Protestants alike continued to use their religion as a means of identifying themselves and their heritage as separate from and hostile to the other community. Religious adherence here remained until the end of the 20th century at a considerably higher level than in the rest of the United Kingdom.

In its almost universal refusal to assert itself aggressively and negatively against outsiders, European Christianity resembles or is indeed part of the wider question of the problem of a European political identity. If official enthusiasts for European integration accepted no self-imposed limitations on their attempts to encourage European populations to identify themselves as Europeans, they would stress the racial and religious distinctiveness of a white, western, Catholic/Protestant people, threatened (by low birth rates and constant immigration pressure) with demographic and cultural invasion by Orthodox Slavs from the east and Arab and North African Muslims from the south, all seeking to rob west Europeans of their hard-won prosperity. Add a blatant anti-Americanism towards an alien force to the west, and there might be powerful ethnic appeal that could span the left-right spectrum. This could be considerably more potent in forging a European identity than the current practice of financing a few road schemes and culture festivals.

Neither the European Commission nor the churches will do anything of the kind. For at least the older members of European political and religious elites memories of the absolute horror produced when a generation in some European countries embarked on a similar enterprise remain strong. The number of members of European political and religious elites willing to break rank and overtly exploit the potential reservoir of aggressive identities to be found here remains small and limited to a fringe, shunned by 'respectable' colleagues. The fact that the issues involved are latently alive and very sensitive only reinforces determination not to follow a path involving any kind of such risks. Eastward extension of membership of the EU will be a cautious matter, particularly as it extends to Islamic Turkey, an issue to which the large Moslem minorities within many EU countries are relevant. It is significant, both that the waiting list for membership of all these countries has been established, and that it takes a particular order: first Catholic and Protestant countries: Poland, the Czech Republic, Hungary and the Baltic states; then some Orthodox Slav lands; then Turkey. ${ }^{21}$

European patriotism has to be of the intellectual Habermasian kind: a love of the humane and liberal qualities of the constitution; certainly not an atavistic passion for the fatherland. ${ }^{22}$ Such a phenomenon considerably lacks mobilising power and will never excite the passions. On the other 
hand, it is highly unlikely to lead to the torture or murder of anyone, and is not without a certain quiet reality in public consciousness. Very much the same is true of European Christianity.

Matters could, of course, change, as memories of the first half of the 20th century fade. Already much of the ecumenical, kindly face of contemporary churches seems to have become a bureaucratised process with little meaning for its professional practitioners; sometimes they seem to be just doing a job, speaking their ecumenical lines just as any corporate executive speaks the lines of the firm currently employing him. ${ }^{23}$ This facade could eventually crack in the face of a true fundamentalist revivalism, though there are today no signs that this is imminent. The very non-bureaucratic, charismatic, crusading and in many respects reactionary revivalism of Pope John Paul II has been utterly committed to reconciliation and friendly dialogue with other Christians, with Jews, Muslims and others, extending to direct contact with Fidel Castro. True, Opus Dei, the secretive movement which grew alongside the Franco dictatorship in Spain and has been involved in various non-democratic situations, remains at the heart of the Vatican, but it works quietly and never engages in any anti-democratic or anti-ecumenical mobilisations.

Meanwhile, the specifically political activity of European Christianity is just possibly embarking on its third major reorientation since the start of the democratic era. The first reorientation, in the late 19th century, involved coming to terms with the secular liberal state-a process which took Catholics and Protestants in very different directions. The second, complete by the mid20th century, involved becoming a rallying point for conservative and capitalist but democratic forces against socialism. The third, if it develops, would align Christians and their former socialist antagonists against neoliberalism. There are some indications of this. The Lutheran churches of northern Europe have for some time maintained a social gospel; the Church of England long ago left its role of being 'the Tory Party at prayer', and has taken up a number of essentially left-of-centre political positions on issues of the day. The generally conservative papacy of John Paul II has been notable for its defence of the welfare state and of labour rights. ${ }^{24}$

It is important to understand what might be going on here accurately. It is not that the churches 'have become social democrats'. The proper role of churches is to assist mankind to approach God and to tend to the interests of their own organisations. From time to time, however, this fundamental mission leads them to follow empirically parallel paths to various forms of secular politics, leading to varied de facto alliances. At present the European religious and the social democratic agenda coincide in that both have, in their slightly different ways, been bruised by the abrasive form of contemporary interpretations of individualism embodied in neo-liberalism, the current ruling ideology of most of the advanced world.

Neo-liberalism can, however, claim its own alliance with religion. The relatively pure neo-liberalism of the British and US right seems to make 
increased space for the charitable work of churches and other voluntary organisations in its reduction of the role of the welfare state, which classic social democrats often seemed to want to have a monopoly in this sphere. Further, the conservative stance of most neo-liberals on non-economic issues also chimes with many religious preferences. Similarly, the social democratic form of neo-liberalism, the so-called 'third way', stresses its elective affinity with the 'third arm', the voluntary sector, in welfare, and erects a form of communitarianism in the non-economic sphere to balance the individualism it advocates within the economy. However, in both cases the dominance of the joint stock company maximising shareholder value and deregulating all forms of protection against its power seems to have hollowed out the ostensible pluralism of these forms of neo-liberalism. Concepts such as the stakeholder economy, economic mutualism of the type embodied by British building societies, and similar phenomena which might occupy the space between the state and shareholder capitalism have been squeezed to the margin, as neo-liberalism neither knows how to nor wants to prevent the latter from occupying the whole of the space.

This development seems to be a more salient problem in European societies, including the UK, than in the USA, where there is far less social and ethical criticism of shareholder domination, and where religious groups themselves increasingly use the form of the joint stock company to build their own organisations. Thus European Christians and social democrats seem to stand together in an only partially mutually recognised alliance of those standing for values and practices which are being pushed aside during the current interpretation of the unavoidable logic of modernisation. Even if such an alliance were to become more explicit, giving European religions a renewed focus, it would remain an alliance of the quiet forces, of those bruised by the brusqueness of change and power, apart from the centres of vigorous energy.

\section{Notes}

1 C. Crouch, Social Change in Western Europe, ch. 9, Oxford, Oxford University Press, 1999; European Values Group, The European Values Study 1981-1990: Summary Report, Aberdeen: Gordon Cook Foundation, 1992.

2 The US case is well discussed elsewhere in this book. For the Latin American situation, see D. Martin, Tongues of Fire: The Explosion of Protestantism in Latin America, Oxford, Blackwell, 1990.

3 The internal diversity of the constituent nations of the United Kingdom is nowhere more apparent than in the field of religion. England here therefore means England, and neither Britain nor the UK as a whole.

4 See several chapters in S. Bruce ed., Religion and Modernization: Sociologists and Historians Debate the Secularization Thesis, Oxford, Clarendon Press, 1992.

5 Crouch, op. cit.

6 D. Martin, A General Theory of Secularisation, Oxford, Blackwell, 1978.

7 G. Davie, 'Contrastes dans l'héritage religieux en Europe', in G. Davie and 
D. Hervieu-Léger, Identités religieuses en Europe, Paris, La Découverte, 1994; G. Davie, Religion in Europe, Oxford, Oxford University Press, 2000.

8 R. Kecskes and C. Wolf, 'Christliche Religiosität: Konzepte, Indikatoren, Messinstrumente', Kölner Zeitschrift für Soziologie und Sozialpsycholgie, 45, 2, 270-87, 1993.

9 G. Hamberg, Studes in the Prevalence of Religious Beliefs and Religious Practives in Contemporary Sweden, Uppsala, S. Academiae Ubsaliensis, 1990.

10 Davie, op. cit. (1994 and 2000); and Hervieu-Léger, D. 'La religion des européens: Modernité, religion, sécularisation', in Davie and Hervieu-Léger, op cit.

11 Davie, op. cit., 2000.

12 Crouch, op. cit., ch. 7; R. Lesthaeghe, 'The Second Demographic Transition in Western Countries: An Interpretation', in K. O. Mason and A.-M. Jensen, eds. Gender and Family Change in Industrialized Societies, Oxford: Clarendon Press, 1995; R. Lesthaeghe and G. Moors, 'Living Arrangements, Socio-Economic Position, and Values among Young Adults: A Pattern Description for France, West Germany, Belgium, and the Netherlands, 1990', in D. Coleman, ed. Europe's Population in the 1990s, Oxford: Oxford University Press, 1996.

13 R. J. Campiche, 'Dilution ou recomposition? Confession en Suisse', in Davie and Hervieu-Léger, op. cit.

14 J.-P. Willaime, Laïcité et religion en France', in Davie and Hervieu-Léger, op. cit.

15 L. Voyé, 'Belgique: Crise de la civilisation parossiale et recomposition de la croire', in Davie and Hervieu-Léger, op. cit.

16 R. Cipriani, 'Diffused Religion and New Values in Italy', in J. A. Beckford and T. Luckmann, eds., The Changing Face of Religion, London, Sage, 1989; E. Pace, 'Désenchantement religieux en Italie', in Davie and Hervieu-Léger, op. cit.

17 Campiche, op cit., p. 104.

18 Nazis were of course not Christian. Fascists often were, especially in the more conservative forms that dominated in Portugal, Spain and, very briefly, in pre-nazi Austria.

19 For a good study of the social politics of Christian democracy, see K. van Kersbergen, Social Capitalism: A study of Christian democracy and the welfare state, London, Routledge, 1995.

20 This was not the case in Portugal and Spain, where the Catholic church hierarchy did very little to stand in the way of the dictatorships.

21 The early admission of Orthodox Greece, and the early position in the queue of Cyprus, are not really exceptions. Greece as classical Greece has always been granted a kind of honorary membership of western Christendom.

22 J. Habermas, Die postnationale Konstellation: politische Essays, Frankfurt am Main, Suhrkamp, 1998.

23 For an interesting example, see the image of the Church of England revealed in Humphrey Carpenter's biography of the former Archbishop of Canterbury, Robert Runcie, The Reluctant Archbishop, London, Hodder \& Stoughton, 1996.

24 See the publications of the Pontifical Academy of Social Sciences, Vatican City. 